\title{
Socioeconomic, demographic and lifestyle-related factors associated with unhealthy diet: a cross-sectional study of university students
}

\author{
Roberto Martinez-Lacoba ${ }^{1,2^{*}}$ (D), Isabel Pardo-Garcia ${ }^{1,2}$, Elisa Amo-Saus ${ }^{1}$ and Francisco Escribano-Sotos ${ }^{1,2}$
}

\begin{abstract}
Background: Food habits are important to promote and maintain good health throughout life, and unhealthy diet is a modifiable and preventable risk factor. University students are a key group of adults among whom to promote healthy lifestyles. The aim of this study is to determine the factors associated with unhealthy diet in a sample of university students.

Methods: An electronic cross-sectional survey was conducted with university students ( $n=593)$ from inland Spain, during the 2016-2017 academic year. The survey collected information on the participants' food habits using an annual food frequency questionnaire. We also collected socioeconomic and demographic data and lifestyle-related information. A multivariate logistic regression was used for analysis.

Results: The multivariate logistic regression revealed that the factors associated with an unhealthy diet were: being male, being underweight compared to the reference category (normal weight), having a mother of low socioeconomic status, the family home not being in the university city and, finally, studying a non health-related course

Conclusion: Among students of the University of Castilla-La Mancha, being male, being underweight, the family home not being in the university city, having a mother of low socioeconomic status, and, finally, not studying a health-related course are the factors associated with a lower quality diet. Following a healthy diet is key in reducing the health costs of non-communicable diseases, and ensuring an acceptable long-term quality of life in populations.
\end{abstract}

Keywords: Unhealthy diet, Socioeconomic factors, Demographic factors, lifestyle related factors, University students

\section{Background}

Food habits are important to promote and maintain good health throughout life [1]. An unhealthy diet is a modifiable and preventable risk factor, which, together with other elements such as physical inactivity, use of tobacco and other harmful substances, has led to non-communicable chronic diseases (NCDs) becoming the leading cause of disability and early death, impacting on quality of life and the organization of healthcare systems $[2,3]$. The global impact of NCD on healthcare

\footnotetext{
* Correspondence: roberto.mlacoba@uclm.es

${ }^{1}$ Facultad de Ciencias Económicas y Empresariales, Universidad de Castilla-La Mancha (UCLM), Plaza de la Universidad, 1 C.P.: 02071, Albacete, Spain

${ }^{2}$ Centro de Estudios Sociosanitarios (CESS), Universidad de Castilla-La Mancha (UCLM), Albacete, Spain
}

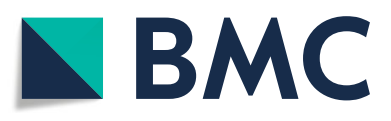

(อ) The Author(s). 2018 Open Access This article is distributed under the terms of the Creative Commons Attribution 4.0 International License (http://creativecommons.org/licenses/by/4.0/), which permits unrestricted use, distribution, and reproduction in any medium, provided you give appropriate credit to the original author(s) and the source, provide a link to the Creative Commons license, and indicate if changes were made. The Creative Commons Public Domain Dedication waiver (http://creativecommons.org/publicdomain/zero/1.0/) applies to the data made available in this article, unless otherwise stated.

expenditure is predicted to rise constantly over the coming years [4], thus representing a risk not only for human health but also for development and economic growth [5], since diet quality is influenced by socioeconomic position [6].

The Mediterranean diet is healthy and greater adherence to this diet has beneficial effects on health and can, among other things, ease the economic burden on the healthcare sector [7-11]. Although this diet is originally from the countries of the Mediterranean basin [12], thanks to its declaration as part of the Intangible Cultural Heritage of Humanity by UNESCO [13], and in view of the health benefits its provides, this food pattern has been exported to other countries [14, 15]. 
University students are a key group of adults among whom to promote healthy lifestyles [16], as they do not generally have good eating habits [17]. University courses can be used for improving food patterns [18], with the aim of reducing the social and health risks associated with an unhealthy diet. However, interventions and policies should study implementation conditions before application [19]. Previous studies in university population have used various indicators to descriptively analyse eating habits and diet quality [20-22], and the association between diet quality and lifestyle-related factors, social, economic and demographic characteristics $[16,23-25]$. To the best of our knowledge, no study conducted with Spanish university students has studied unhealthy diets using an adherence to Mediterranean diet score as an indicator [26], and its association with lifestyle-related factors and socioeconomic and demographic characteristics. The aim of this study is to determine the factors associated with an unhealthy diet, so as to assist decision makers in promoting food and eating policies which reduce the risk of NCDs and the associated economic problems, thus ensuring enhanced quality of life among the population.

\section{Method}

Design

This study was conducted in the Autonomous Community of Castilla-La Mancha, situated in the centre of Spain. Students from the University of Castilla-La Mancha (a multi-campus institution) in the cities of Albacete, Ciudad Real, Cuenca, Talavera de la Reina and Toledo participated in the study. An electronic self-completed cross-sectional survey conducted during the 2016-2017 academic year was used to gather data. The students could ask researchers for assistance if they had any doubts. All the students were informed of the aims of the study and participated voluntarily. The survey included questions about socioeconomic, demographic, anthropometric characteristics, physical activity, and food intake. A pre-test was performed during the 2015-2016 academic year to confirm face and content validity of the survey. Items were refined according to the comments from the pre-test. The data were collected using the Survey Monkey software [27].

\section{Participants and environment}

A total of 1077 students participated in the study $(n=1077)$. The final sample comprised 593 participants ( $n=593,249$ men and 344 women). This sample was representative of the study population (15,278 students, 3971 Health Sciences and 11,307 Social Sciences), and the CI was established at $95 \%$ with an estimated maximum sampling error of $\pm 4 \%$. The inclusion criterion was that participants were enrolled on Social Sciences courses (i.e.: Business \& Administration, Economics, Law \& Economics...) or Health Sciences courses (i.e.: Nursing, Medicine, Pharmacy...) during the 2016-2017 academic year in the University of Castilla-La Mancha. On the other hand, participants were excluded if: i) did not complete the questionnaire/invalid data (i.e.: careless or insufficient effort); ii) energy intake under/over limit; iii) BMI > 35; iv) missing data. Figure 1 shows the data cleaning process.

\section{Dietary assessment}

We used a self-reported annual Food Frequency Questionnaire (FFQ) to collect data on food intake. The FFQ was adapted from similar FFQs previously validated in Spanish adult population [28-31]. Participants were asked about their consumption of 141 foods divided into 12 groups: i) dairy products; ii) eggs, meat and fish; iii) vegetables; iv) legumes; v) cereal; vi) oils and fats; vii) fruit; viii) sweets and desserts; ix) beverages; $\mathrm{x}$ ) spices; xi) precooked products; and xii) fast food. Energy intake was calculated by multiplying the frequency of consumption in years, the grams per portion and the kilocalories (kcal) for each food (Additional file 1: Table S1). The energy intake for each type of food was taken from the Spanish Food Composition Database [32].

\section{Variables included}

\section{Socioeconomic and demographic characteristics}

The socioeconomic and demographic characteristics collected were gender, age, family home, parents' current employment, degree in which the students were enrolled, type of residence during the academic year (family home without cooking; university residence without cooking; shared flat with cooking; and shared flat without cooking).

The parents' occupational social class (mother and father) was established following the $4^{\text {th }}$ Spanish National Classification of Occupations using two categories [33]. Occupational social class was considered an indicator of socioeconomic status [34, 35]. Participants whose parents belonged to the group of non-manual workers were associated with high socioeconomic status and those whose parents belonged to the group of manual workers were considered of low socioeconomic status (Additional file 1: Table S2).

We differentiated between students enrolled on healthrelated degrees (Medicine, Nursing or Pharmacy) and Social Sciences related degrees. Respondents who reported living in a shared flat and cooking were considered to be independent and to cook regularly for themselves.

\section{Lifestyle-related factors}

Self-reported height and weight were collected. Body mass index (BMI) was calculated using anthropometric 


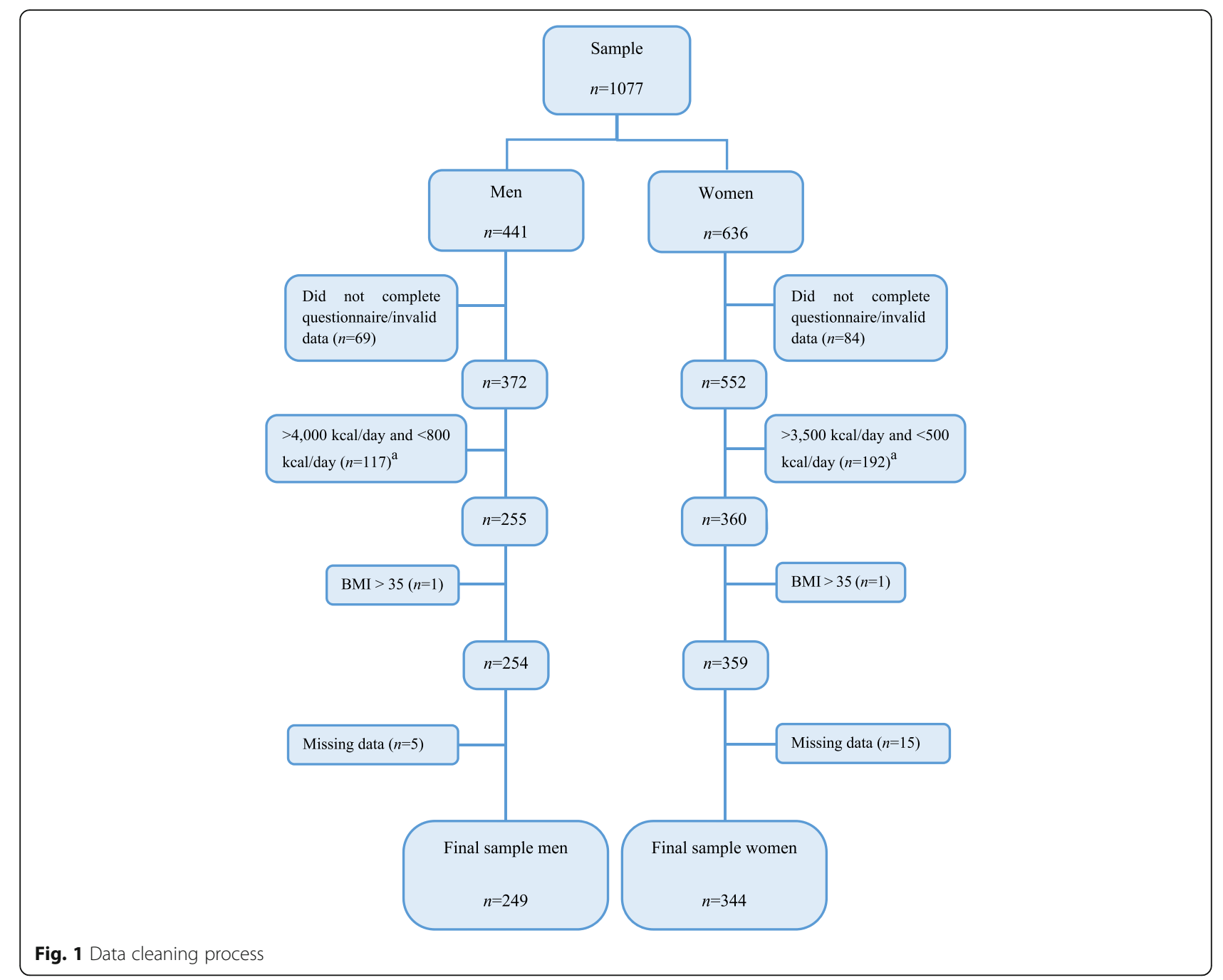

data $\left(\mathrm{kg} / \mathrm{m}^{2}\right)$ and classified into 4 categories: underweight $(\mathrm{BMI}<18.5)$; normal weight $(18.5 \leq \mathrm{BMI} \leq 24.9)$; overweight $(25 \leq$ BMI $\leq 29.9)$ and obesity $(B M I \geq 30)$ [36]. The participants were considered to present a healthy level of physical activity if they accumulated at least 60 minutes of moderate-intensity physical activity daily (brisk walking, trekking, bicycling, swimming, basketball or volleyball) and 30 minutes of intense physical activity daily (running, mountain biking, singles tennis, football, or aerobic exercise) or a combination of both $[37,38]$. Tobacco use, and consumption of other harmful substances (i.e.: cannabis, cocaine, amphetamines...) were also included in the questionnaire.

\section{Unhealthy diet}

We defined unhealthy diet by using an index of adherence to Mediterranean diet. We used the FFQ to estimate adherence to Mediterranean diet according to the validated MEDI-LITE score [7, 26]. This indicator comprises nine food categories: fruit, vegetables, legumes, cereal grains, fish, meat and meat products, dairy products, alcohol, and olive oil. The possible score ranges from 0 (minimum) to 18 (maximum). We converted the index into a dichotomous variable named unhealthy diet, using the median as the reference [39]. Diet was considered unhealthy (score 1) if the score on the index was $\leq 9$ (median), and adequate if it was $>9$ (score 0) (Additional file 1: Table S3).

\section{Missing data analysis}

Multiple imputation procedure was performed to deal with missing data, under the missing at random assumption (MAR) [40, 41]. We excluded from analyses all participants who did not complete the full questionnaire or presented invalid data $(n=153)$. Participants were included in multiple imputation analyses if they completed the questionnaire, despite they presented extreme values (i.e.: overreport of kilocalories/day, BMI $>35$ ) or missing 
values. Extreme values were considered as missing data. Variables with missing data were: unhealthy diet (32.14\%), his/her father's socioeconomic status (2.60\%), his/her mother's socioeconomic status $(0.008 \%)$ and body mass index $(0.002 \%)$. We compared observed and imputed data for unhealthy diet variable, because there is a large fraction of imputed data [42] (Additional file 1: Table S6). Variables included in imputation model were presented in Additional file 1. We performed two multiple imputation analyses with 5 and 30 subsets (number of iterations=20). We also analysed interactions in imputation models (Additional file 1: Table S5).

\section{Statistical analysis}

The statistical model used was multivariate logistic regression. The dichotomous dependent variable was unhealthy diet, created using the MEDI-LITE index. The independent variables were related to: a) lifestyle: body mass index, level of physical activity, tobacco use, and use of harmful substances; and b) socioeconomic and demographic characteristics: socioeconomic status of father and mother, main family home, whether or not the participant cooked for him or herself during the academic year, and the subject area of the degree course. We analysed the interactions between the variables included in the study (Additional file 1: Table S4). The correlations were analysed using Spearman's Correlation
Coefficient [43]. All the statistical analyses were conducted using RStudio software [44], and Microsoft Excel spreadsheet software [45].

\section{Results}

The main diagonal of the correlation matrix (Fig. 2) shows graphically the distribution of the variables. Table 1 shows the characteristics of the sample $(n=593)$ according to gender.

The students' mean age was 20.21 years and $58 \%$ of the respondents were female. The mean height was 169.80 and mean weight was $66.02 \mathrm{~kg}$, with significant differences between men and women. A total of $47.90 \%$ of the students presented an unhealthy diet, with a greater difference in the men $(53.81 \%)$. Most of the participants were normal weight $(74.42 \%$ of women $72.29 \%$ of men). The underweight percentage was higher in the women $(10.17 \%)$ and the overweight percentage was higher in the men $(23.70 \%)$. The percentage of males who did healthy physical activity was higher (55.42\% versus $25.58 \%$ ).

Of the fathers, $43.84 \%$ had non-manual occupations (high socioeconomic status) compared to $37.60 \%$ of the mothers. These differences were greater when divided by gender, since $32.27 \%$ of female students' mothers had a non-manual occupation, compared to $44.98 \%$ of male students' mothers. A majority of students

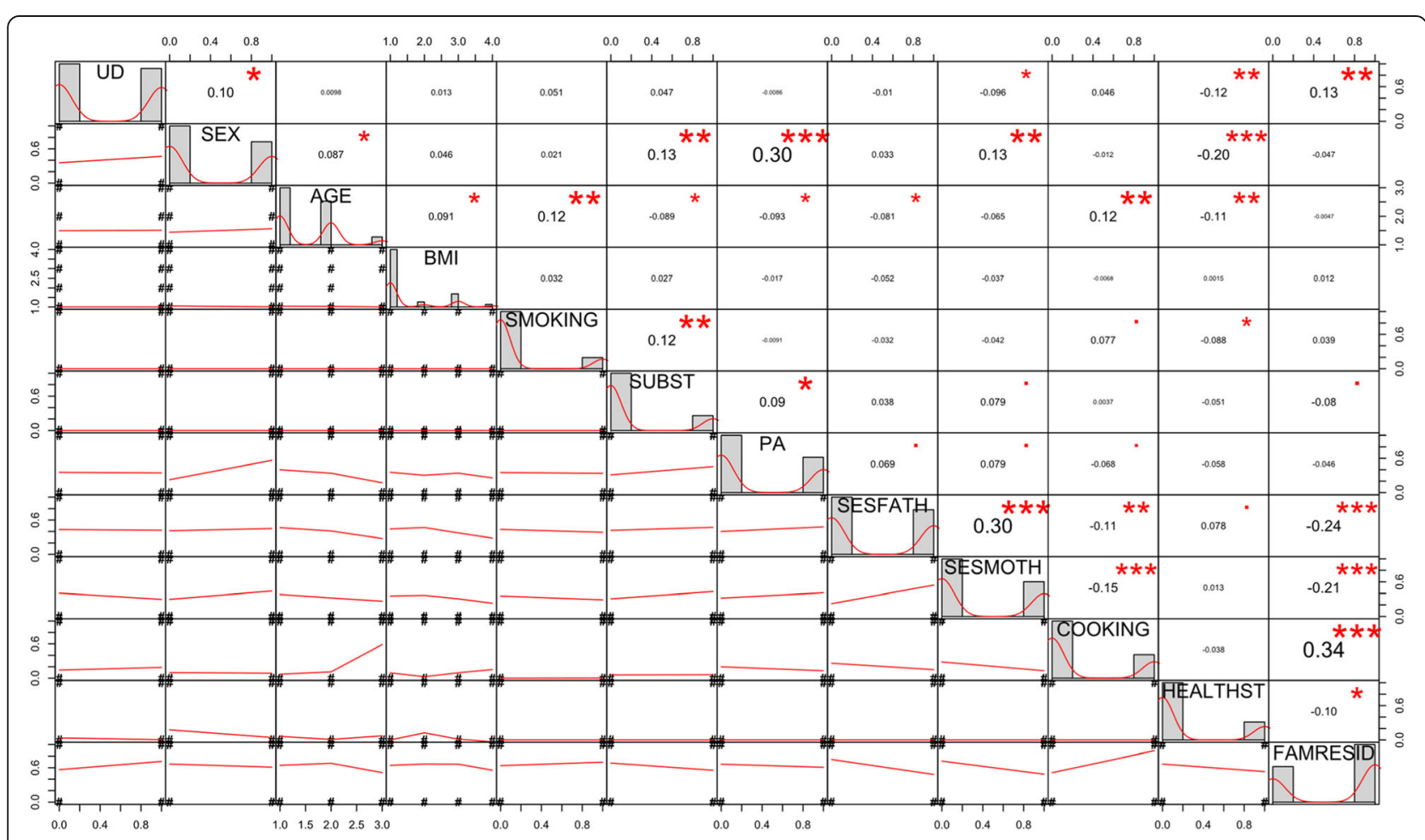

Fig. 2 Correlation matrix between variables. Abbreviations: UD unhealthy diet, BMI body mass index, SUBST substance use, PA physical activity, SESFATH father's socioeconomic status, SESMOTH mother's socioeconomic status, HEALTHST health-related studies, FAMRESID family home 
Table 1 Characteristics of the study population

\begin{tabular}{|c|c|c|c|c|}
\hline & Total $(n=593)$ & Women $(n=344)$ & Men $(n=249)$ & \\
\hline & $\%^{\mathrm{a}}$ & $\%^{\mathrm{a}}$ & $\%^{\mathrm{a}}$ & $P$ value \\
\hline Unhealthy diet & 47.90 & $150(43.60)$ & $134(53.81)$ & 0.018 \\
\hline \multicolumn{5}{|c|}{ a) Socioeconomic and demographic characteristics } \\
\hline Age (years), mean & 20.21 & 20.06 & 20.42 & \multirow[t]{2}{*}{0.176} \\
\hline SD & 3.23 & 3.25 & 3.21 & \\
\hline \multicolumn{5}{|l|}{ SES father/ mother } \\
\hline High & 43.84 / 37.60 & 42.44 / 32.27 & $45.78 / 44.98$ & \multirow[t]{2}{*}{$0.560 / 0.004$} \\
\hline Low & $56.16 / 62.40$ & $57.56 / 67.73$ & $54.22 / 55.02$ & \\
\hline \multicolumn{5}{|l|}{ Family home } \\
\hline Other town & 61.72 & 63.66 & 59.04 & \multirow[t]{2}{*}{0.290} \\
\hline University city & 38.28 & 36.34 & 40.96 & \\
\hline \multicolumn{5}{|c|}{ Cooks for him or herself during the academic year } \\
\hline Yes & 29.17 & 29.65 & 28.51 & \multirow[t]{2}{*}{0.834} \\
\hline No & 70.83 & 70.35 & 71.49 & \\
\hline \multicolumn{5}{|l|}{ Degree course } \\
\hline Health Sciences & 23.95 & 31.10 & 14.06 & \multirow[t]{2}{*}{$<0.001$} \\
\hline Social Sciences & 76.05 & 68.90 & 85.94 & \\
\hline \multicolumn{5}{|c|}{ b) Lifestyle-related factors } \\
\hline Weight (kg) mean & 66.02 & 59.54 & 74.96 & \multirow[t]{2}{*}{$<0.001$} \\
\hline SD & 12.65 & 10.04 & 10.18 & \\
\hline Height (cm) mean & 169.80 & 164.01 & 177.80 & \multirow[t]{2}{*}{$<0.001$} \\
\hline SD & 9.23 & 5.99 & 6.55 & \\
\hline \multicolumn{5}{|l|}{ BMI } \\
\hline Underweight & 6.41 & 10.17 & 1.20 & $<0.001$ \\
\hline Normal weight & 73.52 & 74.42 & 72.29 & 0.627 \\
\hline Overweight & 16.86 & 11.92 & 23.70 & $<0.001$ \\
\hline Obesity & 3.21 & 3.49 & 2.81 & 0.821 \\
\hline \multicolumn{5}{|l|}{ HPA } \\
\hline Yes & 38.11 & 25.58 & 55.42 & \multirow[t]{2}{*}{$<0.001$} \\
\hline No & 61.89 & 74.42 & 44.58 & \\
\hline \multicolumn{5}{|l|}{ Tobacco use } \\
\hline Yes & 16.36 & 15.70 & 17.27 & \multirow[t]{2}{*}{0.691} \\
\hline No & 83.64 & 84.30 & 82.73 & \\
\hline \multicolumn{5}{|c|}{ Other harmful substances } \\
\hline Yes/occasional & 20.57 & 15.99 & 26.91 & \multirow[t]{2}{*}{0.002} \\
\hline No & 79.43 & 84.01 & 73.09 & \\
\hline
\end{tabular}

Gender related-differences between means or percentages calculated using the $t$-Student test and $x^{2}$

$H P A$, healthy physical activity, BMI body mass index, SES socioeconomic status.

avalues presented are percentages, unless indicated otherwise.

reported their family home was in different town from the university $(61.72 \%)$, did not cook during the academic year $(70.83 \%)$, and did not smoke $(83.64 \%)$ or use harmful substances $(79.43 \%)$, although male students reported higher consumption (occasional or regular) of substances (26.91\% compared to $15.99 \%$ of females). A total of $23.95 \%$ of the respondents studied a health-related degree course although the difference was greater among the women $(31.10 \%$ compared with $14.06 \%$ of the men).

The upper part of Fig. 2 shows that the highest correlations are only moderate $(0.30<|\rho|<0.70)$. The lower 
part shows that the positive or negative relationships between the variables. Unhealthy diet is positively related to gender and family home, and negatively to the maternal socioeconomic status and the subject area of the student's degree course.

The results of the multivariate logistic regression analysis for the associations between the sociodemographic and lifestyle-related factors and unhealthy diet as dependent variable are shown in Table 2. Table 2 includes the results from complete-case analysis and multiple imputation analyses $(\mathrm{m}=5$ and $\mathrm{m}=30)$. The results from both analyses produce similar results for odds ratio on studied variables and complete-case analysis showed comparable, but higher standard error than multiple imputation analysis (Additional file 1: Table S7). The factors associated with unhealthy diet were: being male, being underweight relative to the category of reference category (normal weight), low maternal socioeconomic status, the participant's family habitually residing in a town away from the university and, finally, studying a health-related degree course.

\section{Discussion}

The results of this work show that the factors associated with low-quality diet are: gender, location of family home, body mass index, mother's socioeconomic status and subject area of studies. Age, tobacco or substance use, and cooking during the academic year are not associated with unhealthy diet. These findings are important for public health. Our results help to identify the characteristics of individuals requiring intervention to encourage a healthy diet. Non-communicable diseases such as cardiovascular disease, type 2 diabetes mellitus, and cancer account for about $10 \%$ of direct medical costs [46], and are lifestyle-related [47]. Diet and nutrition, among others, are important factors in health promotion, and primary prevention is an effective and affordable way to prevent chronic disease [48]. Hence, early recognition of unhealthy diets in youths could help to avoid the healthcare utilisation and costs associated with non-communicable diseases [4], and could also improve quality of life.

The characteristics of the variables included in this study are similar to those used in various studies in university population $[20,49-52]$. In line with other studies $[53,54]$, our work also reports a greater prevalence of underweight in women and overweight in men. As regards the socioeconomic and demographic characteristics, the results reveal that age is not a significant factor in diet quality [51, 55], although other studies have found an association [23, 24]. It is worth remembering, however, that studies in university populations refer to a small age range and, so, the age variable may have little impact on diet quality.
The female participants presented higher diet quality, coinciding with various studies in university population $[24,51,52]$, and in adult population [56, 57]. Nonetheless, there exists one work in an adult population showing higher diet quality in men [58], contrasting with our results. In the present work, higher maternal socioeconomic status was inversely related to unhealthy diet. Coinciding with our study, a number of studies in adult population have shown that diet quality is associated with higher socioeconomic status [59-63], and in an adolescent population (13-19 years), higher maternal socioeconomic status, measured by means of educational level, was positively associated with better dietary habits [64].

Our findings also show that when the family home was not in the university city, the participant did not live at home and, consequently, presented a less healthy diet. In contrast, when a student's family lives in the university city, the participant usually lives in the family home and thus maintains better dietary patterns [52]. Whether participants cooked for themselves or not was not associated with diet quality, in contrast to another study showing a relationship between cooking meals for oneself and higher diet quality [65]. Finally, studying a health-related degree course was associated with higher diet quality [50,66]. In contrast, there is one work showing that knowledge of nutrition does not affect diet and healthy lifestyle decision-making [67].

Regarding lifestyle-related factors, our results show that underweight is associated with lower diet quality compared to normal weight participants. Being overweight and obesity were not associated with diet quality, coinciding with various studies in university population $[20,23,24,55]$. This, however, contrast with findings in adult population $[58,60]$. On the other hand, there exists one study in student population finding that overweight and obesity are associated with lower diet quality [51]. These differences in findings about the association between BMI and diet quality may be a result of participants' social desirability bias.

Several studies have shown that smoking [56, 60, 62], and low levels of physical activity are factors associated with an unhealthier dietary pattern [56, 57, 60, 62, 68]. However, in student population there is no consensus on whether smoking and doing healthy physical activity are associated with diet quality. In our smoking and physical activity were not associated with unhealthy diet $[20,51,52,55]$, although one study has shown that physical activity is associated with healthier dietary patterns [24]. Finally, the present work finds no association between the consumption of harmful substances and diet quality [24].

This study has some limitations. First, the use of a FFQ may give rise to dietary measurement error [69], impacting on the estimation of relative risks. 
Table 2 Association between socioeconomic, demographic and lifestyle-related factors and unhealthy diet: multivariate logistic regression analysis

\begin{tabular}{|c|c|c|c|c|c|c|}
\hline \multirow[t]{2}{*}{ Variables } & \multicolumn{2}{|c|}{ Complete-case analysis $(n=593)$} & \multicolumn{2}{|c|}{ Multiple imputation $(n=924, m=5)$} & \multicolumn{2}{|c|}{ Multiple imputation $(n=924, m=30)$} \\
\hline & OR & $95 \% \mathrm{Cl}$ & $\mathrm{OR}$ & $95 \% \mathrm{Cl}$ & OR & $95 \% \mathrm{Cl}$ \\
\hline \multicolumn{7}{|c|}{ a) Socioeconomic and demographic } \\
\hline \multicolumn{7}{|l|}{ Age } \\
\hline $15-19$ & 1.00 & Reference & & & & \\
\hline $20-24$ & 1.00 & $(0.70 ; 1.43)$ & 0,93 & $(0.67 ; 1.28)$ & 1.02 & $(0.73 ; 1.42)$ \\
\hline $25-25+$ & 0.92 & $(0.46 ; 1.84)$ & 0,97 & $(0.51 ; 1.84)$ & 0.95 & $(0.53 ; 1.70)$ \\
\hline \multicolumn{7}{|l|}{ Gender } \\
\hline Woman & 1.00 & Reference & & & & \\
\hline Man & $1.75^{*}$ & $(1.20 ; 2.55)$ & $1.80^{*}$ & $(1.26 ; 2.57)$ & $1.78^{*}$ & $(1.26 ; 2.51)$ \\
\hline \multicolumn{7}{|l|}{ SES father } \\
\hline Low & 1.00 & Reference & & & & \\
\hline High & 1.24 & $(0.86 ; 1.78)$ & 1.22 & $(0.88 ; 1.68)$ & 1.21 & $(0.86 ; 1.70)$ \\
\hline \multicolumn{7}{|l|}{ SES mother } \\
\hline Low & 1.00 & Reference & & & & \\
\hline High & $0.63^{*}$ & $(0.44 ; 0.92)$ & $0.63^{*}$ & $(0.45 ; 0.89)$ & $0.64^{*}$ & $(0.45 ; 0.92)$ \\
\hline \multicolumn{7}{|l|}{ Family home } \\
\hline University city & 1.00 & Reference & & & & \\
\hline Other town & $1.69^{*}$ & $(1.15 ; 2.48)$ & $1.89^{*}$ & $(1.36 ; 2.61)$ & $1.69^{*}$ & $(1.19 ; 2.41)$ \\
\hline \multicolumn{7}{|c|}{ Cooks for him or herself during the academic year } \\
\hline No & 1.00 & Reference & & & & \\
\hline Yes & 0.98 & $(0.66 ; 1.45)$ & 0.90 & $(0.61 ; 1.31)$ & 0.99 & $(0.68 ; 1.46)$ \\
\hline \multicolumn{7}{|l|}{ Degree course } \\
\hline Social Sciences & 1.00 & Reference & & & & \\
\hline Health Sciences & $0.63^{*}$ & $(0.42 ; 0.95)$ & $0.59^{*}$ & $(0.41 ; 0.87)$ & $0.65^{*}$ & $(0.46 ; 0.93)$ \\
\hline \multicolumn{7}{|l|}{ b) Lifestyle-related } \\
\hline \multicolumn{7}{|l|}{ BMI } \\
\hline Normal weight & 1.00 & Reference & & & & \\
\hline Underweight & $2.31^{*}$ & $(1.14 ; 4.82)$ & $2.19^{*}$ & $(1.07 ; 4.45)$ & $2.28^{*}$ & $(1.16 ; 4.46)$ \\
\hline Overweight & 0.81 & $(0.51 ; 1.28)$ & 0.74 & $(0.43 ; 1.26)$ & 0.78 & $(0.50 ; 1.22)$ \\
\hline Obesity & 1.04 & $(0.39 ; 2.74)$ & 1.04 & $(0.43 ; 2.52)$ & 1.03 & $(0.42 ; 2.51)$ \\
\hline \multicolumn{7}{|l|}{ HPA } \\
\hline No & 1.00 & Reference & & & & \\
\hline Yes & 0.82 & $(0.57 ; 1.18)$ & 0.82 & $(0.60 ; 1.11)$ & 0.80 & $(0.57 ; 1.13)$ \\
\hline \multicolumn{7}{|l|}{ Tobacco use } \\
\hline No & 1.00 & Reference & & & & \\
\hline Yes & 1.20 & $(0.76 ; 1.90)$ & 1.20 & $(0.78 ; 1.83)$ & 1.21 & $(0.79 ; 1.86)$ \\
\hline \multicolumn{7}{|c|}{ Other harmful substances } \\
\hline No & 1.00 & Reference & & & & \\
\hline Yes/occasional & 1.29 & $(0.84 ; 1.97)$ & 1.33 & $(0.91 ; 1.95)$ & 1.28 & $(0.86 ; 1.91)$ \\
\hline
\end{tabular}


Furthermore, given the characteristics of food frequency questionnaires, a memory bias might have influenced the results. A social desirability bias might also have occurred, whereby respondents reported healthy habits which did not exist. The collection of weight and height was self-reported. However, a recent study has shown that self-reported anthropometric data are valid in young adults [70]. Nevertheless, the study also has some strengths. We also used the criterion of recommended intake in kilocalories [71], which presents no substantial differences to other methods [72], to exclude participants with implausible energy intakes. We dealt with missing data by using a multiple imputation method. Imputed values on unhealthy diet variable were comparable with the observed values. Focusing on multivariate logistic regression, this method produced similar estimates on odd ratio for unhealthy diet than a complete-case analysis and a comparable standard error.

\section{Conclusion}

This study identifies factors associated with an unhealthy diet. The results showed that being male, underweight, the family home not being in the university city, low maternal socioeconomic status and not studying a health-related degree course are all factors associated with low diet quality. Maintaining a healthy diet is of great importance in reducing health costs related to non-communicable diseases and ensuring acceptable long-term quality of life. The findings of the present study may serve to develop food policies that help to promote healthy lifestyles in the student population.

\section{Additional file}

Additional file 1: Data cleaning, calculation of variables, statistical analysis; Table S1. Conversion of intake frequencies to number of intakes per year; Table S2. Occupational social class based on the occupations in the questionnaire; Table S3. Adjustment of daily/weekly frequencies; Table S4. Association between socioeconomic, demographic and lifestyle related factors and unhealthy diet: multivariate logistic regression with interaction of variables; Table S5. Interaction effects in imputation models ( $n=924)$ : multivariate logistic regression; Table S6. Comparison between observed data and imputed data for unhealthy diet variable; Table S7. Coefficients and standard error from multivariate logistic regression. (DOCX $61 \mathrm{~kb})$

\section{Abbreviations}

BMI: Body mass index; FAMRESID: Family home; FFQ: Food frequency questionnaire; HEALTHST: Health-related studies; NCD: Non-communicable chronic diseases; OR: Odd ratio; PA: Physical activity; SD: Standard deviation; SESFATH: Father's socioeconomic status; SESMOTH: Mother's socioeconomic status; SUBST: Substance use; UD: Unhealthy diet

\section{Acknowledgements}

The authors thank all professors and colleagues for their time spent. We specially thank Miguel Ángel Gómez Borja for helping us with the survey software. We would like to thank two reviewers and editor for their constructive suggestions on earlier versions of this paper.

\section{Funding}

This study has not been funded.

\section{Availability of data and materials}

The datasets used and/or analysed during the current study are available from the corresponding author on reasonable request.

\section{Authors' contributions}

The author's responsibilities were as follows: RML, IPG, EAS, FES designed the study; RML performed the statistical analysis; RML, EAS, FES interpreted the results; RML, IPG, EAS wrote the manuscript. All authors read and approved the final manuscript.

\section{Ethics approval and consent to participate}

All the students were informed of the aims of the study and participated voluntarily. The completion of the questionnaire was considered to imply informed consent. The study worked with anonymised information. This research was conducted according to the guidelines laid down in the Declaration of Helsinki. The Clinical Research Ethics Committee of the Health Unit of Cuenca certified that the study doesn't need ethics approval according to national guidelines (nr: 2018/P1018).

Consent for publication

Not applicable.

Competing interests

The authors declare that they have no competing interest.

\section{Publisher's Note}

Springer Nature remains neutral with regard to jurisdictional claims in published maps and institutional affiliations.

Received: 14 March 2018 Accepted: 25 October 2018

Published online: 07 November 2018

\section{References}

1. World Health Organization, Food and Agriculture Organization of the United Nations. Diet, Nutrition and the Prevention of Chronic Diseases. In: Report of a Joint WHO/FAO Expert Consultation. Series 916. Geneva: World Health Organization; 2003. http://apps.who.int/iris/bitstream/10665/42665/1/ WHO_TRS_916.pdf.

2. Lim SS, Vos T, Flaxman AD, Danaei G, Shibuya K, Adair-Rohani H, et al. A comparative risk assessment of burden of disease and injury attributable to 67 risk factors and risk factor clusters in 21 regions, 1990-2010: A systematic analysis for the Global Burden of Disease Study 2010. Lancet. 2012;380: 2224-60. https://doi.org/10.1016/S0140-6736(12)61766-8.

3. Mayer-Fulkes DA. A Survey of Macro Damages from Non-Communicable Chronic Diseases: Another Challenge for Global Governance. Glob Econ J. 2011;11. https://doi.org/10.2202/1524-5861.1725.

4. Muka T, Imo D, Jaspers L, Colpani V, Chaker L, van der Lee SJ, et al. The global impact of non-communicable diseases on healthcare spending and national income: a systematic review. Eur J Epidemiol. 2015;30:251-77. https://doi.org/10.1007/s10654-014-9984-2.

5. Bloom DE, Cafiero E, Jané-Llopis E, Abrahams-Gessel S, Bloom LR, Fathima S, et al. The Global Economic Burden of Noncommunicable Diseases. Geneva: World Economic Forum; 2011. http://apps.who.int/medicinedocs/ documents/s18806en/s18806en.pdf

6. Drewnowski A, Darmon N. The economics of obesity: dietary energy density and energy cost. Am J Clin Nutr. 2005;82(Suppl):265S-73S.

7. Sofi F, Macchi C, Abbate R, Gensini GF, Casini A. Mediterranean diet and health status: an updated meta-analysis and a proposal for a literaturebased adherence score. Public Health Nutr. 2013;17:2769-82. https://doi.org/ 10.1017/S1368980013003169.

8. Estruch R, Ros E, Salas-Salvadó J, Covas M-I, Corella D, Arós F, et al. Primary Prevention of Cardiovascular Disease with a Mediterranean Diet. N Engl J Med. 2013;368:1279-90. https://doi.org/10.1056/NEJMoa1200303.

9. Martinez-Gonzalez MA, Bes-Rastrollo M, Serra-Majem L, Lairon D, Estruch R, Trichopoulou A. Mediterranean food pattern and the primary prevention of chronic disease: Recent developments. Nutr Rev. 2009;67(Suppl 1):111-6. https://doi.org/10.1111/j.1753-4887.2009.00172.x. 
10. Di Carlo A, Baldereschi M, Inzitari D. Eating the Mediterranean Style: A Tasty Way for Stroke Prevention. Agric Agric Sci Procedia. 2016;8:762-8. https:// doi.org/10.1016/j.aaspro.2016.02.063.

11. Lock K, Smith RD, Dangour AD, Keogh-Brown M, Pigatto G, Hawkes C, et al. Health, agricultural, and economic effects of adoption of healthy diet recommendations. Lancet. 2010;376:1699-709. https://doi.org/10.1016/ S0140-6736(10)61352-9.

12. Bach-Faig A, Berry EM, Lairon D, Reguant J, Trichopoulou A, Dernini S, et al. Mediterranean diet pyramid today. Science and cultural updates. Public Health Nutr. 2011;14:2274-84. https://doi.org/10.1017/S1368980011002515.

13. UNESCO. Representative List of the Intangible Cultural Heritage of Humanity. 2010. https://ich.unesco.org/en/RL/mediterranean-diet-00884. Accessed 15 Jan 2018

14. Wang T, Heianza Y, Sun D, Huang T, Ma W, Rimm EB, et al. Improving adherence to healthy dietary patterns, genetic risk, and long term weight gain: gene-diet interaction analysis in two prospective cohort studies. BMJ. 2018;360:j5644. https://doi.org/10.1136/bmj.j5644.

15. Wade AT, Davis CR, Dyer KA, Hodgson JM, Woodman RJ, Keage HAD, et al. Including pork in the Mediterranean diet for an Australian population: Protocol for a randomised controlled trial assessing cardiovascular risk and cognitive function. Nutr J. 2017;16:1-19. https://doi.org/10.1186/s12937-017-0306-x.

16. Chourdakis M, Tzellos T, Papazisis G, Toulis K, Kouvelas D. Eating habits, health attitudes and obesity indices among medical students in northern Greece. Appetite. 2010;55:722-5. https://doi.org/10.1016/j.appet.2010.08.013.

17. Sánchez-Ojeda MA, De Luna-Bertos E. Hábitos de vida saludable en la población universitaria. Nutr Hosp. 2015;31:1910-9. https://doi.org/10.3305/ nh.2015.31.5.8608

18. Neslişah R, Emine AY. Energy and nutrient intake and food patterns among Turkish university students. Nutr Res Pract. 2011;5:117-23. https://doi.org/10. 4162/nrp.2011.5.2.117.

19. Horodyska K, Luszczynska A, Hayes CB, O'Shea MP, Langøien LJ, Roos G, et al. Implementation conditions for diet and physical activity interventions and policies: An umbrella review. BMC Public Health. 2015;15. https://doi. org/10.1186/s12889-015-2585-5.

20. García-Meseguer MJ, Burriel FC, García CV, Serrano-Urrea R. Adherence to Mediterranean diet in a Spanish university population. Appetite. 2014;78: 156-64. https://doi.org/10.1016/j.appet.2014.03.020.

21. Irazusta Astiazaran A, Ruiz Litago F, Gil Orozco S, Gil Goikouria FJ, Irazusta AJ. Hábitos de vida de los estudiantes de enfermería [Habits of life in nursing students]. Zainak. 2005;27:99-107.

22. Papadaki A, Hondros G, Scott JA, Kapsokefalou M. Eating habits of University students living at, or away from home in Greece. Appetite. 2007:49:169-76. https://doi.org/10.1016/j.appet.2007.01.008.

23. Fabián C, Pagán I, Ríos JL, Betancourt J, Cruz SY, González AM, et al. Dietary Patterns and their Association with Socio- demographic Characteristics and Perceived Academic Stress of College Students in Puerto Rico. P R Health Sci J. 2013:32:36-43.

24. Moreno-Gómez C, Romaguera-Bosch D, Tauler-Riera P, Bennasar-Veny M, Pericas-Beltran J, Martinez-Andreu S, et al. Clustering of lifestyle factors in Spanish university students: the relationship between smoking, alcohol consumption, physical activity and diet quality. Public Health Nutr. 2012;15: 2131-9. https://doi.org/10.1017/\$1368980012000080.

25. Arguello M, Bautista Y, Carvajal J, De Castro K, Díaz D, Escobar M, et al. Estilos de vida en estudiantes del área de la salud de Bucaramanga. Rev Psicol Univ Antioquía. 2009;1:27-41 http://aprendeenlinea.udea.edu.co/ revistas/index.php/psicologia/article/view/10019.

26. Sofi F, Dinu M, Pagliai G, Marcucci R, Sofi F, Dinu M, et al. Validation of a literaturebased adherence score to Mediterranean diet: the MEDI-LITE score. Int J Food Sci Nutr. 2017;68:757-62. https://doi.org/10.1080/09637486.2017.1287884.

27. SurveyMonkey. SurveyMonkey: Free online survey software \& questionnaire tool. 2012 www.surveymonkey.com. http://www.surveymonkey.com/.

28. Vioque J, Navarrete-Muñoz E-M, Gimenez-Monzó D, García-de-la-Hera GF, Young IS, et al. Reproducibility and validity of a food frequency questionnaire among pregnant women in a Mediterranean area. Nutr J. 2013;12 http://www.nutritionj.com/content/12/1/26.

29. Willet WC, Sampson L, Stampfer MJ, Rosner B, Bain C, Witschi J, et al. Reproducibility and validity of a semiquantitative food frequency questionnaire. Am J Epidemiol. 1985;122:51-65.

30. Martin-Moreno JM, Boyle P, Gorgojo L, Maisonneuve P, Fernandez-Rodriguez JC, Salvini S, et al. Development and validation of a food frequency questionnaire in Spain. Int J Epidemiol. 1993;22:512-9. https://doi.org/10.1093/ije/22.3.512.
31. Ruiz Moreno E, Del Pozo de la Calle S, Cuadrado Vives C, Valero Gaspar T, Ávila Torres JM, Belmonte Cortés S, et al. Encuesta de nutrición de la Comunidad de Madrid. Madrid: Fundación Española de Nutrición y Consejería de sanidad de la Comunidad de Madrid; 2014

32. Red BEDCA. Agencia Española de Seguridad Alimentaria y Nutrición. Base de Datos Española de Composición de Alimentos. 2010; http://www.bedca.net/. Accessed 7 Oct 2017.

33. Domingo-Salvany A, Bacigalupe A, Carrasco JM, Espelt A, Ferrando J, Borrell C. Propuestas de clase social neoweberiana y neomarxista a partir de la Clasificación Nacional de Ocupaciones 2011. Gac Sanit. 2013;27:263-72. https://doi.org/10.1016/j.gaceta.2012.12.009.

34. Ozen AE, Bibiloni MDM, Murcia MA, Pons A, Tur JA. Adherence to the Mediterranean diet and consumption of functional foods among the Balearic Islands' adolescent population. Public Health Nutr. 2015;18:659-68. https://doi.org/10.1017/\$1368980014000809.

35. Martínez E, Llull R, del Mar Bibiloni M, Pons A, Tur JA. Adherence to the mediterranean dietary pattern among balearic islands adolescents. $\mathrm{Br}$ J Nutr. 2010;103:1657-64. https://doi.org/10.1017/S0007114509993576.

36. World Health Organization. Body mass index - BMI. 2017. http://www.euro. who.int/en/health-topics/disease-prevention/nutrition/a-healthy-lifestyle/ body-mass-index-bmi. Accessed 26 Nov 2017.

37. Grupo Colaborativo de la Sociedad Española de Nutrición Comunitaria. Guías alimentarias para la población española; la nueva pirámide de la alimentación saludable. Nutr Hosp. 2016;33(Suplemento 8):1-48. https://doi. org/10.20960/nh.827.

38. World Health Organization. Global Recommendations on Physical Activity for Health. Geneva: World Health Organization; 2010. http://www.who.int/ dietphysicalactivity/factsheet_recommendations/en/

39. Tognon G, Hebestreit A, Lanfer A, Moreno LA, Pala V, Siani A, et al. Mediterranean diet, overweight and body composition in children from eight European countries: Cross-sectional and prospective results from the IDEFICS study. Nutr Metab Cardiovasc Dis. 2014;24:205-13. https://doi.org/ 10.1016/j.numecd.2013.04.013.

40. van Buuren S, Groothuis-Oudshoorn K. Mice: Multivariate Imputation by Chained Equations in R. J Stat Softw. 2011;45. https://doi.org/10.18637/jss.v045.103.

41. Pedersen AB, Mikkelsen EM, Cronin-Fenton D, Kristensen NR, Pham TM, Pedersen L, et al. Missing data and multiple imputation in clinical epidemiological research. Clin Epidemiol. 2017;9:157-66.

42. Sterne JAC, White IR, Carlin JB, Spratt M, Royston P, Kenward MG, et al. Multiple imputation for missing data in epidemiological and clinical research: potential and pitfalls. BMJ. 2009;338(b:2393):157-60.

43. Mangiafico SS. An R Companion for the Handbook of Biological Statistics, version 1.3.2. 2015. rcompanion.org/documents/RCompanionBioStatistics.pdf.

44. RStudio Team. RStudio: Integrated Development for R. 2015. http://www. rstudio.com/.

45. Microsoft. Excel 2016. 2016. https://products.office.com/es-es/excel.

46. Kimokoti RW, Millen BE. Diet, the Global Obesity Epidemic, and Prevention. J Am Diet Assoc. 2011;111:1137-40. https://doi.org/10.1016/j.jada.2011.05.016.

47. OECD. Health at a Glance 2017: OECD Indicators. Paris: OECD Publishing; 2017.

48. Slawson DL, Fitzgerald N, Morgan KT. Position of the Academy of Nutrition and Dietetics: The Role of Nutrition in Health Promotion and Chronic Disease Prevention. J Acad Nutr Diet. 2013;113:972-9.

49. Al-Rethaiaa AS, Fahmy A-EA, Al-Shwaiyat NM. Obesity and eating habits among college students in Saudi Arabia: a cross sectional study. Nutr J. 2010:9. https://doi.org/10.1186/1475-2891-9-39.

50. Amaral D, Hernández N, Basabe N, Roncadio AM, Pablo R, Arroyo M. Satisfacción corporal y calidad de la dieta en estudiantes universitarias del País Vasco. Endocrinol y Nutr. 2012;59:239-45. https://doi.org/10.1016/j. endonu.2012.01.007

51. Arroyo Izaga M, Rocandio Pablo AM, Ansotegui Alday L, Pascual Apalauza E, Salces Beti I, Rebato OE. Calidad de la dieta, sobrepeso y obesidad en estudiantes universitarios. Nutr Hosp. 2006;21:673-9.

52. Cervera Burriel F, Serrano Urrea R, Vico García C, Milla Tobarra M, García Meseguer MJ. Hábitos alimentarios y evaluación nutricional en una población universitaria. Nutr Hosp. 2013;28:438-46. https://doi.org/10.3305/ nh.2013.28.2.6303.

53. Satalic Z, Colic Baric I, Keser I. Diet quality in Croatian university students: Energy, macronutrient and micronutrient intakes according to gender. Int J Food Sci Nutr. 2007;58:398-410. https://doi.org/10.1080/09637480701252393.

54. Soriano JM, Moltó JC, Mañes J. Dietary Intake and Food Pattern Among University. Nutr Res. 2000;20:1249-58. 
55. Hall L, Tejada-Tayabas LM, Monárrez-Espino J. Breakfast Skipping, Anxiety, Exercise, and Soda Consumption are Associated with Diet Quality in Mexican College Students. Ecol Food Nutr. 2017;56:218-37. https://doi.org/ 10.1080/03670244.2017.1299010.

56. Leon-Munoz LM, Guallar-Castillon P, Graciani A, Lopez-Garcia E, Mesas AE, Aguilera MT, et al. Adherence to the Mediterranean Diet Pattern Has Declined in Spanish Adults. J Nutr. 2012;142:1843-50. https://doi.org/10. 3945/jn.112.164616.

57. Patino-Alonso MC, Recio-Rodríguez Jl, Belio JFM, Colominas-Garrido R, Lema-Bartolomé J, Arranz AG, et al. Factors associated with Adherence to the Mediterranean Diet in the Adult Population. J Acad Nutr Diet. 2014;114: 583-9. https://doi.org/10.1016/j.jand.2013.07.038.

58. Hu EA, Toledo E, Diez-Espino J, Estruch R, Corella D, Salas-Salvado J, et al. Lifestyles and Risk Factors Associated with Adherence to the Mediterranean Diet: A Baseline Assessment of the PREDIMED Trial. PLoS One. 2013;8: e60166. https://doi.org/10.1371/journal.pone.0060166.

59. Darmon N, Drewnowski A. Does social class predict diet quality? Am J Clin Nutr. 2008;87:1107-17.

60. Fransen HP, Boer JMA, Beulens JWJ, De Wit GA, Bueno-HB, Hoekstra J, et al. Associations between lifestyle factors and an unhealthy diet. Eur J Public Health. 2017;27:274-8. https://doi.org/10.1093/eurpub/ckw190.

61. Livingstone K, Olstad D, Leech R, Ball K, Meertens B, Potter J, et al. Socioeconomic Inequities in Diet Quality and Nutrient Intakes among Australian Adults: Findings from a Nationally Representative Cross-Sectional Study. Nutrients. 2017;9:1092. https://doi.org/10.3390/nu9101092.

62. Mullie P, Clarys P, Hulens M, Vansant G. Dietary patterns and socioeconomic position. Eur J Clin Nutr. 2010;64:231-8. https://doi.org/10.1038/ejcn.2009.145.

63. Backholer K, Spencer E, Gearon E, Magliano DJ, McNaughton SA, Shaw JE, et al. The association between socio-economic position and diet quality in Australian adults. Public Health Nutr. 2016;19:477-85. https://doi.org/10. 1017/S1368980015001470.

64. Nilsen SM, Krokstad S, Holmen TL, Westin S. Adolescents' health-related dietary patterns by parental socio-economic position, the Nord-Trøndelag health study (HUNT). Eur J Public Health. 2010;20:299-305. https://doi.org/ 10.1093/eurpub/ckp137.

65. Thorpe MG, Kestin M, Riddell LJ, Keast RSJ, Sarah A. Diet quality in young adults and its association with food-related behaviours. Public Health Nutr. 2013;17:1767-75. https://doi.org/10.1017/S1368980013001924.

66. Pérez-Gallardo L, Mingo Gómez T, Bayona Marzo I, Ferrer Pascual MÁ, Márquez Calle E, Ramírez Domínguez R, et al. Calidad de la dieta en estudiantes universitarios con distinto perfil académico. Nutr Hosp. 2015;31: 2230-9. https://doi.org/10.3305/nh.2015.31.5.8614.

67. Rizo-Baeza M, González-Brauer N, Cortés E. Calidad de la dieta y estilos de vida en estudiantes de Ciencias de la Salud. Nutr Hosp. 2014;29:153-7. https://doi.org/10.3305/nh.2014.29.1.6761.

68. Heerman WJ, Jackson N, Hargreaves M, Mulvaney SA, Schlundt D, Wallston KA, et al. Clusters of Healthy and Unhealthy Eating Behaviors Are Associated With Body Mass Index Among Adults. J Nutr Educ Behav. 2017:49:415-21.e1. https://doi.org/10.1016/j.jneb.2017.02.001.

69. Freedman LS, Schatzkin A, Midthune D, Kipnis V. Dealing with dietary measurement error in nutritional cohort studies. J Natl Cancer Inst. 2011 103:1086-92. https://doi.org/10.1093/jnci/djr189.

70. Nikolaou CK, Hankey CR, Lean MEJ. Accuracy of on-line self-reported weights and heights by young adults. Eur J Public Health. 2017;27:898-903.

71. Willett W. Nutritional epidemiology. Oxford: Oxford University Press; 1998.

72. Rhee JJ, Sampson L, Cho E, Hughes MD, Hu FB, Willett WC. Comparison of methods to account for implausible reporting of energy intake in epidemiologic studies. Am J Epidemiol. 2015;181:225-33. https://doi.org/10. 1093/aje/kwu308.

Ready to submit your research? Choose BMC and benefit from:
- fast, convenient online submission
- thorough peer review by experienced researchers in your field
- rapid publication on acceptance
- support for research data, including large and complex data types
- gold Open Access which fosters wider collaboration and increased citations
- maximum visibility for your research: over 100M website views per year
At BMC, research is always in progress.
Learn more biomedcentral.com/submissions

